\title{
Rosuvastatin relieves myocardial ischemia/reperfusion injury by upregulating PPAR- $\gamma$ and UCP2
}

\author{
LING WANG, RONG LIN, LANGTAO GUO and MEIMAN HONG \\ Department of Cardiovascular Medicine, Quanzhou First Hospital, \\ Affiliated to Fujian Medical University, Quanzhou, Fujian 362000, P.R. China
}

Received July 31, 2017; Accepted April 18, 2018

DOI: $10.3892 / \mathrm{mmr} .2018 .9062$

\begin{abstract}
The present study aimed to investigate whether pretreatment with rosuvastatin (RS) can provide cardioprotection in a myocardial ischemia/reperfusion (MI/R) model. The protective effect of RS on myocardial oxygen-glucose deprivation/reperfusion (OGD/R) injury was also evaluated by upregulating peroxisome proliferator-activated receptor- $\gamma$ (PPAR- $\gamma)$. In the present study, MI/R model was established and activities of superoxide dismutase (SOD), lactate dehydrogenase (LDH), creatine kinase-muscle/brain (CK-MB), malondialdehyde (MDA), and troponin I/T were measured. The infarct size was measured using Evans blue staining and cell viability was measured by MTT assay. Reactive oxygen species (ROS) levels were assessed by flow cytometry. Caspase-9, cytochrome c (cyt c), mitochondrial uncoupling protein 2 (UCP2) and PPAR- $\gamma$ expression levels were detected by reverse transcription-quantitative polymerase chain reaction and western blotting. The results indicated that RS increased SOD activity, and decreased LDH, CK-MB, MDA and troponin $\mathrm{I} / \mathrm{T}$ activities. The effect of RS was reversed by atractyloside (ATR). RS inhibited myocardial infarct size, downregulated expression of caspase- 9 and cyt $\mathrm{c}$ and upregulated expression of UCP2 and PPAR- $\gamma$ by inhibiting ATR. Furthermore, the results indicated that $\mathrm{RS}$ promoted cardiomyocyte viability, inhibited LDH release, reduced ROS production, decreased expression of caspase- 9 and cyt $\mathrm{c}$, and increased expression of UCP2 and PPAR $-\gamma$ following OGD/R damage. Therefore, the present study demonstrated that RS protects primary myocardial cells against OGD/R injury by regulating PPAR- $\gamma$ and $\mathrm{UCP} 2$. RS may be a promising therapeutic agent for treatment of $\mathrm{MI} / \mathrm{R}$ injury.
\end{abstract}

Correspondence to: Dr Ling Wang, Department of Cardiovascular Medicine, Quanzhou First Hospital, Affiliated to Fujian Medical University, 250 East Street, Quanzhou, Fujian 362000, P.R. China E-mail: lingwang_1w@163.com

Key words: rosuvastatin, myocardial ischemia, reperfusion injury, PPAR- $\gamma$, UCP2

\section{Introduction}

Arteriosclerotic cardiovascular disease is life-threatening and has a high mortality rate in China (1). Atherosclerotic plaque erosion and plaque rupture are the primary pathologies associated with acute coronary syndrome, which may lead to formation of complete or incomplete occlusive thrombi and myocardial ischemia $(2,3)$. In the treatment of myocardial ischemia, revascularization is necessary to restore the blood flow $(4,5)$. However, following blood supply restoration, ischemic tissues produce excess free radicals which cause further severe injury to the ischemic tissues known as ischemia/reperfusion (I/R) injury (6,7).

Statins down-regulate low density lipoprotein (LDL) receptors by inhibiting 3-hydroxy-3-methyl-glutaryl-CoA reductase and reduce cholesterol synthesis in hepatocytes $(8,9)$. Previous studies have indicated that statins can also serve a variety of physiological functions, including improving endothelial function, reducing inflammation and delaying hardening of the arteries $(10,11)$. Statins are also involved in the synthesis of extracellular matrix proteins (12) It has also been indicated that rosuvastatin (RS) stabilizes arterial plaques and exhibits a stronger lipid-lowering capacity compared with other statins $(13,14)$. However, the function and mechanism of action of RS in myocardial ischemia/reperfusion (MI/R) remain to be elucidated.

Peroxisome proliferator-activated receptor- $\gamma(\operatorname{PPAR}-\gamma)$ is a ligand-inducible transcription factor which can regulate a number of biological processes associated with the cardiovascular system (15). PPAR- $\gamma$ belongs to nuclear receptor superfamily which is primarily expressed in adipose tissues (16). Previous studies have also indicated that PPAR- $\gamma$ agonists reduce inflammation and myocardial injury caused by MI/R $(17,18)$. Therefore, PPAR- $\gamma$ is a novel treatment target used to prevent heart disease complications including heart failure (19). However, the mechanism of PPAR- $\gamma$ in MI/R needs to be extensively studied.

Uncoupling proteins (UCPs) are located in the inner mitochondrial membrane and act as anion carrier proteins (20). Previous studies have demonstrated that activation of UCP 3 could reduce ATP synthesis by uncoupling oxidative phosphorylation, lowering proton gradient, decreasing ROS generation, transporting fatty acid anions and reducing peroxide-associated damage $(21,22)$. It has been reported that UCP3 is able to prevent mitochondrial injury (23). It has also been demonstrated 
that the expression levels of UCP1 increased in IR myocardium and served a critical role in both cardioprotection against $\mathrm{MI} / \mathrm{R}$ injury and induction of ischemic preconditioning (24). Recently, mitochondrial uncoupling protein 2 (UCP2) has been reported to serve a role in cardiac hypertrophy and myocardial injury $(25,26)$. Nevertheless, the precise role and mechanism of $\mathrm{UCP} 2$ in cardioprotection remain unclear.

PPAR subtypes have been implicated in transcriptional regulation of UCP, and PPARs are expressed in many organs, such as the heart and pancreas (27). It has been demonstrated that PPAR $-\gamma$ could regulate the transcription of UCP2 in INS-1E cells (28). Based on the aforementioned data, the authors of the present study hypothesized that PPAR $-\gamma$ and $\mathrm{UCP} 2$ may be associated with cardioprotection and MI/R.

Therefore, the present study investigated the effect of RS on oxidative stress in an in vivo model of MI/R. The effects of $\mathrm{RS}$ and atractyloside (ATR) on myocardial infarct size were also studied. It was further detected whether RS affected cardiomyocyte viability, LDH activity and ROS content in vitro following oxygen-glucose deprivation/reperfusion (OGD/R) damage. Furthermore, the possible involvement of caspase-9, cytochrome c (cyt c), PPAR- $\gamma$ and UCP2 in the MI/R injury was also verified.

\section{Materials and methods}

Ischemia-reperfusion (MI/R) model. A total of 48 healthy adult male New Zealand white rabbits (weight, $4.0-5.0 \mathrm{~kg}$; age, 6 months) were purchased from Guangdong Medical Laboratory Animal Center (Foshan, China). Rabbits were randomly divided into 4 groups, with 12 rabbits in each group. Rabbits had free access to food and water and were housed at $20^{\circ} \mathrm{C}$ with $60-70 \%$ humidity and a $12 \mathrm{~h}$ light/dark cycle. Animals were fasted $12 \mathrm{~h}$ prior to surgery. All experimental animals used in the present study received ethical approval for experimental research. The project protocol was approved by the Institutional Review Board of Fujian Province Medical Association. Prior to surgery, anesthesia was induced by intramuscular injection of ketamine $(25-40 \mathrm{mg} / \mathrm{kg})$ and acepromazine $(1-2 \mathrm{mg} / \mathrm{kg})$. In the sham group, a suture was placed around the coronary artery, without induction of $\mathrm{MI} / \mathrm{R}$. In the MI/R group, rabbits were subjected to ischemia for $30 \mathrm{~min}$ followed by $120 \mathrm{~min}$ of reperfusion. In the RS group, RS (CRESTOR ${ }^{\circledR}$; AstraZeneca, Cambridge, UK) was administrated once at a dose of $5 \mathrm{mg} / \mathrm{kg}$ $12 \mathrm{~h}$ prior to MI/R. In the RS + ATR group, RS was administrated once at a dose of $5 \mathrm{mg} / \mathrm{kg} 12 \mathrm{~h}$ prior to MI/R, and ATR (Chengdu Herbpurify Co., Ltd., Chengdu, China) was administered at a dose of $5 \mathrm{mg} / \mathrm{kg} 30 \mathrm{sec}$ prior to reperfusion. To establish a MI/R model, during the experiment, left anterior descending arteries were obstructed for $40 \mathrm{~min}$ in the $\mathrm{MI} / \mathrm{R}$ group rabbits, but not in the sham group rabbits. Left anterior descending arteries were untied $40 \mathrm{~min}$ later and reperfused.

TCC and Evans blue staining. As previously described (29), TTC/Evans blue (Sigma-Aldrich; Merck KGaA, Darmstadt, Germany) staining was used to measure the cardiomyocyte risk area. At the end of the myocardial I/R protocols, evans blue (3\%; $0.5 \mathrm{ml}$ ) was injected into the vena cava at room temperature in order to detect the area-at-risk (AAR). When the remaining blood had been washed out, the right ventricle was trimmed away and the left ventricle was cut into 2 -mm-thick slices. The slices were subsequently stained with $2 \%$ TTC at $37^{\circ} \mathrm{C}$ for $15 \mathrm{~min}$ in order to measure the area of necrosis (AN). The AN area was identified by the non-staining region, whereas the live area was stained red. The cardiac injury was presented as AN/AAR.

Establishment of cardiomyocyte MI/R model via OGD/R injury. The MI/R cell model was established on the basis of previous investigations (30-33). SD rats (8-12 weeks; male:female, 1:4; $\mathrm{n}=15$ ) were obtained from Guangdong Medical Laboratory Animal Center. The animals had free access to food and water and were housed at $25^{\circ} \mathrm{C}$, with $45-65 \%$ humidity and a $12 \mathrm{~h}$ light/dark cycle. The animals were mated to produce the neonatal rats, as described previously. Six 1-3 day-old neonatal SD rats were used to isolate cardiomyocytes, as previously described (32). In brief, the collected hearts were minced into pieces of $\sim 1 \mathrm{~mm}^{3}$. Minced tissue was resuspended in dissociation buffer $(60 \mathrm{mg}$ trypsin and $40 \mathrm{mg}$ collagenase type $\mathrm{II}$ in $100 \mathrm{ml} \mathrm{H}_{2} \mathrm{O}_{2}$ ) and incubated in preheated tissue processing unit (InGeneron Inc., Houston, TX, USA) for $30 \mathrm{~min}$ at $37^{\circ} \mathrm{C}$. The dissociation enzyme activity was inhibited by incubation with cold horse serum (Sigma-Aldrich; Merck $\mathrm{KGaA}$ ) at $37^{\circ} \mathrm{C}$ for $5 \mathrm{~min}$. Fresh dissociation buffer was added to the remaining tissue samples. The above steps were repeated until tissue fragments were completely dissolved. Cell suspensions were collected and centrifuged for $10 \mathrm{~min}$ at $350 \mathrm{x} \mathrm{g}$ at $4^{\circ} \mathrm{C}$. Finally, cell pellets were resuspended in cold $1 \mathrm{x}$ ADS solution (6.8 g NaCl, $4.76 \mathrm{~g}$ HEPES, $0.138 \mathrm{~g} \mathrm{Na}_{2} \mathrm{HPO} 4$, $0.6 \mathrm{~g}$ glucose, $0.4 \mathrm{~g} \mathrm{KCl}$ and $0.051 \mathrm{~g} \mathrm{MgSO}_{4}-7 \mathrm{H}_{2} \mathrm{O}$ in $1000 \mathrm{ml}$ ultrapure water, $\mathrm{pH}$ : 7.35-7.45). To establish an in vitro model of $\mathrm{MI} / \mathrm{R}$, the neonatal rat cardiomyocytes were treated with oxygen-glucose deprivation for $6 \mathrm{~h}$ followed by recovery for $1 \mathrm{~h}$. Neonatal rat cardiomyocytes were randomly assigned to 4 groups. In the control group, cells were cultured in Dulbecco's modified Eagle's medium (DMEM; Gibco; Thermo Fisher Scientific, Inc., Waltham, MA, USA) containing $10 \%$ fetal bovine serum (FBS; Gibco; Thermo Fisher Scientific, Inc.) under $5 \% \mathrm{CO}_{2}$ and $37^{\circ} \mathrm{C}$. In the OGD/R group, the cells were incubated in glucose-free Earle's balanced salt solution (Thermo Fisher Scientific, Inc.) and maintained under 95\% $\mathrm{N}_{2}$ and $5 \% \mathrm{CO}_{2}$ at $37^{\circ} \mathrm{C}$ for $4 \mathrm{~h}$. Cells were subsequently removed and incubated in fresh DMEM containing $10 \% \mathrm{FBS}$ under $5 \% \mathrm{CO}_{2}$ at $37^{\circ} \mathrm{C}$ for $4 \mathrm{~h}$. In the $\mathrm{RS}+\mathrm{OGD} / \mathrm{R}$ group, cells were incubated with RS $(1 \mu \mathrm{M})$ in high glucose DMEM for $3 \mathrm{~h}$ at $37^{\circ} \mathrm{C}$ and washed with PBS, then OGD/R was induced as described for the OGD/R group. In the ATR + RS + OGD/R group, cells were incubated with ATR $(1 \mu \mathrm{M})$ in high glucose DMEM for $1 \mathrm{~h}$ at $37^{\circ} \mathrm{C}$ and washed with PBS. Subsequently, the medium was replaced with DMEM containing RS $(1 \mu \mathrm{M})$ and cells were incubated for $3 \mathrm{~h}$ at $37^{\circ} \mathrm{C}$. Cells were subsequently washed with PBS and OGD/R was induced as described above. Cells in the four groups were subsequently transfected with $50 \mathrm{nM}$ scramble small interfering (si)RNA negative control (NC) or $50 \mathrm{nM}$ PPAR- $\gamma$-siRNA (sequences unavailable; MyBioSource, Inc., San Diego, CA, USA) using Lipofectamine 3000 (Invitrogen; Thermo Fisher Scientific, Inc., Waltham, MA, USA) for $6 \mathrm{~h}$ at $37^{\circ} \mathrm{C}$, according to the manufacturer's protocol. Thus, the grouping was as follows: Control (cells transfected with NC siRNA), control + siPPAR- $\gamma$ (cells transfected with siPPAR- $\gamma$ only), OGD/R (NC siRNA), OGD/R + siPPAR- $\gamma, \mathrm{RS}+\mathrm{OGD} / \mathrm{R}$ (NC siRNA), RS + OGD/R + siPPAR- $\gamma$, ATR + RS + OGD/R $(\mathrm{NC}$ siRNA), ATR + RS + OGD/R + siPPAR- $\gamma$. 
Superoxide dismutase (SOD), lactate dehydrogenase $(L D H)$, creatine kinase-muscle/brain $(C K-M B)$ and malondialdehyde (MDA) activity detection. Blood $(10 \mathrm{ml})$ was collected from the central artery via the rabbit ear using a syringe. The needle was parallel to the artery. A cotton ball was subsequently pressed to the ear to stop the bleeding. Anticoagulants were added and blood was centrifuged at $1,000 \mathrm{x} \mathrm{g}$ at $4^{\circ} \mathrm{C}$ for $10 \mathrm{~min}$. The supernatant from blood samples was collected for subsequent experimentation. The cells from in vitro experiments were also collected and centrifuged for $10 \mathrm{~min}$ at $3,000 \times \mathrm{g}$ and $4^{\circ} \mathrm{C}$, and the supernatant was stored at $-80^{\circ} \mathrm{C}$. The activities of SOD, MDA and LDH were detected using SOD activity detection kit, MDA activity detection kit and LDH-cytotoxicity assay kit, respectively, according to the manufacturer's protocol. The three kits were purchased from Beyotime Institute of Biotechnology (Jiangsu, China). CK-MB activity was measured using Creatine Kinase Activity Assay kit (Sigma-Aldrich; Merck KGaA) according to the manufacturer's protocol.

Cell viability assay. Cell viability in each group was detected by MTT assay. Cells $\left(2 \times 10^{3}\right.$ cells/well) were seeded into 96-well plates $(100 \mu \mathrm{l} /$ well $)$ in serum-free DMEM and incubated at $37^{\circ} \mathrm{C}$ in an incubator with $5 \% \mathrm{CO}_{2}$ for $48 \mathrm{~h}$. Following incubation, cells were treated with $20 \mu$ MTT ( $5 \mathrm{mg} / \mathrm{ml}$; cat. no. M-2128; Sigma-Aldrich; Merck KGaA) solution for $4 \mathrm{~h}$ at $37^{\circ} \mathrm{C}$. Cells were subsequently treated with $10 \mu 1$ dimethylsulfoxide (DMSO) for $15 \mathrm{~min}$ at room temperature. Optical density (OD) value was measured at a wavelength of $490 \mathrm{~nm}$ using a spectrophotometer (Sigma-Aldrich; Merck KGaA).

Enzyme linked immunosorbent assay (ELISA). The activity of troponin I (cat. no. MBS765393) and troponin T (cat. no. MBS056907; both MyBioSource, Inc.) was detected by ELISA according to the manufacturer's protocol. Cultured cells were added into the corresponding wells and the wells were sealed using adhesive tape and maintained at $37^{\circ} \mathrm{C}$ for $90 \mathrm{~min}$. A total of $100 \mu \mathrm{l}$ biotinylated antibody fluids were added into wells. The wells were sealed using adhesive tape and incubated for $60 \mathrm{~min}$ at $4^{\circ} \mathrm{C}$. Chromogenic substrate was added into all wells with the exception of blank wells. Plates were maintained for $10-15 \mathrm{~min}$ in the dark at $37^{\circ} \mathrm{C}$. Subsequently, stop solution was added into each well and mixed immediately for $10 \mathrm{~min}$. Finally, the OD450 value was detected using a microplate reader (Bio-Rad Laboratories, Inc., Hercules, CA, USA).

Evaluation of reactive oxygen species (ROS). Cells were seeded at a density of $1 \times 10^{4} /$ well into a 6 -well plate in a $37^{\circ} \mathrm{C}$ incubator. After 24 h, 2',7'-dichlorodihydrofluorescein diacetate (DCFH-DA; $10 \mu \mathrm{M}$; Sigma-Aldrich; Merck KGaA) was added into the wells and was incubated at $37^{\circ} \mathrm{C}$ for $30 \mathrm{~min}$. The cells were washed in PBS three times (2-3 min each time) to remove the DCFH-DA dye. The evaluation of mitochondrial reactive oxygen species (ROS) was performed using mitoSOX dye (Molecular Probes, USA), which selectively targets the mitochondrial matrix and emits red fluorescence when oxidized by ROS. The cells were stained with $2 \mu \mathrm{M}$ mitoSOX dye and incubated for $15 \mathrm{~min}$ at $37^{\circ} \mathrm{C}$. The cells were subsequently suspended in PBS and analyzed by flow cytometry. ROS levels were measured by FACSCalibur with Cell Quest software version 3.1 (BD Biosciences, San Jose, CA, USA).

Reverse transcription-quantitative polymerase chain reaction (RT-qPCR) assay. The mRNA expression levels of caspase-9, cytochrome c (cyt c), UCP2 and PPAR- $\gamma$ were detected by RT-qPCR. Total RNA from cells and tissues was extracted with TRIzol reagent (Thermo Fisher Scientific, Inc.) according to the manufacturer's protocol. Concentration of extracted RNA was determined using a UV spectrophotometer (Thermo Fisher Scientific Inc.). First-strand cDNA was synthesized using Revert Aid First Strand cDNA Synthesis kit (Thermo Fisher Scientific Inc.). The temperature protocol was set as $25^{\circ} \mathrm{C}$ for $10 \mathrm{~min}, 42^{\circ} \mathrm{C}$ for $50 \mathrm{~min}$ and $70^{\circ} \mathrm{C}$ for $8 \mathrm{~min}$. The mRNA expression levels were evaluated by qPCR using SYBR-Green PCR Master Mix (Applied Biosystems; Thermo Fisher Scientific Inc.) in ABI 7500 Real-time PCR system (Applied Biosystems; Thermo Fisher Scientific Inc.). The PCR thermocycling conditions were as follows: $95^{\circ} \mathrm{C}$ for $5 \mathrm{~min}$, 35 cycles of $95^{\circ} \mathrm{C}$ for $30 \mathrm{sec}$ and $60^{\circ} \mathrm{C}$ for $60 \mathrm{sec}$, followed by a final extension at $72^{\circ} \mathrm{C}$ for $7 \mathrm{~min}$. The results were quantified using the $2^{-\Delta \Delta C q}$ calculation (34). The following specific primers were used: Caspase-9 (product size, 196 bp), 5'-CAGGACCTT GGACAGTGACT-3' (forward), 5'-AATGCCATCCAAGGT CTCGA-3' (reverse); cyt c (product size, 249 bp), 5'-GTTCAG AAGTGTGCCCAGTG-3' (forward), 5'-GTCTGCCCTTTC TCCCTTCT-3' (reverse); UCP2 (product size, 170 bp), 5'-AGA CCATTGCACGAGAGGAA-3' (forward), 5'-AGAAGTGAA GTGGCAAGGGA-3' (reverse); PPAR- $\gamma$ (product size, 164 bp), 5'-AGGGCGATCTTGACAGGAAA-3' (forward), 5'-CGA AACTGGCACCCTTGAAA-3' (reverse); GAPDH (product size, 155 bp), 5'-AACGACCCCTTCATTGACCT-3' (forward), 5'-ATGTTAGTGGGGTCTCGCTC-3' (reverse).

Western blot analysis. The proteins from tissue were extracted using tissue protein extraction kit (Beijing ComWin Biotech Co., Ltd., Beijing, China). The proteins from cells were extracted using a total protein extraction kit (Beijing Solarbio Science \& Technology Co., Ltd.). The concentrations of proteins were detected using Pierce BCA Protein Assay kit (Pierce; Thermo Fisher Scientific, Inc.). Equivalent proteins (30 $\mu \mathrm{g} /$ lane) were separated by $10 \%$ SDS-PAGE gel and transferred onto polyvinylidene fluoride membranes. Proteins were blocked with $5 \%$ skimmed milk at room temperature for $2 \mathrm{~h}$. Primary antibodies against caspase-9 (1:5,000; cat. no. ab2324), cyt c (1:5,000; cat. no. ab28146), UCP2 (1:1,000; cat. no. ab97931), PPAR- $\gamma(1: 1,000$; cat. no. ab223137) and GAPDH (1:2,500; cat. no. ab9485) were from Abcam (Cambridge, MA) and were incubated with the membranes at $4^{\circ} \mathrm{C}$ overnight. Horseradish peroxidase-conjugated mouse anti-rabbit IgG secondary antibody (cat. no. sc-2357; 1:2,000) were from Santa Cruz Biotechnology, Inc. (Dallas, TX, USA). The secondary antibodies were incubated with the membranes at room temperature for $1 \mathrm{~h}$. The images were obtained using enhanced chemiluminescence western blotting detection system (GE Healthcare, Chicago, IL, USA). The data were analyzed using Image Lab Software (version 4.1; Bio-Rad Laboratories, Inc.). 

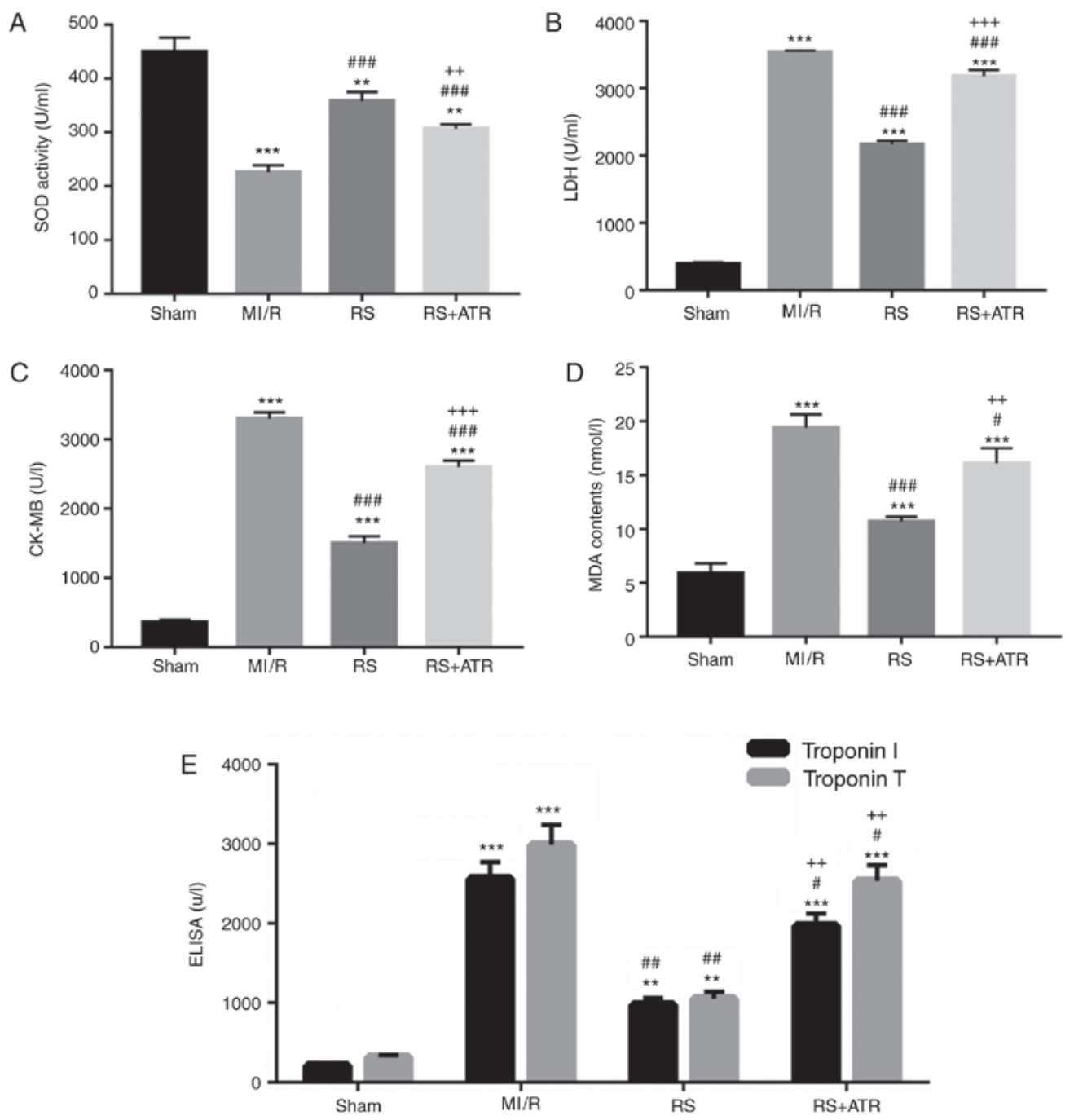

Figure 1. RS increases SOD activity, and decreases LDH, CK-MB, MDA and troponin I/T activities. A total of 48 rabbits were randomly divided into four groups, including the sham group, MI/R group, RS group and RS + ATR group. (A) SOD activity was detected using a commercial kit. (B) LDH activity was measured using a cytotoxicity assay. (C) CK-MB activity was analyzed using a CK-MB assay. (D) MDA activity was analyzed using a MDA activity assay kit. (E) Troponin I/T activities were measured by ELISA. ${ }^{* *} \mathrm{P}<0.01$ and ${ }^{* * * *} \mathrm{P}<0.001$ vs. the sham group; ${ }^{\#} \mathrm{P}<0.05$, ${ }^{\# \#} \mathrm{P}<0.01$ and ${ }^{\# \# "} \mathrm{P}<0.001$ vs. the MI/R group; ${ }^{++} \mathrm{P}<0.01$ and ${ }^{+++} \mathrm{P}<0.001$ vs. the RS group. RS, rosuvastatin; ATR, atractyloside; SOD, superoxide dismutase; LDH, lactate dehydrogenase; CK-MB, creatine kinase-muscle/brain, MDA, malondialdehyde; MI/R, myocardial ischemia/reperfusion.

Statistical analysis. All experimental data were analyzed by one-way analysis of variance followed by Turkey's multiple comparisons test. All values are presented as the mean \pm standard deviation of three experiments. $\mathrm{P}<0.05$ was considered to indicate a statistically significant difference.

\section{Results}

$R S$ increases SOD activity and decreases $L D H, C K-M B$, $M D A$ and troponin I/T activities. To determine whether pretreatment with RS can induce myocardial protection, a rabbit MI/R model was established. The plasma concentrations of SOD, LDH, CK-MB, MDA and troponin I/T at the end of the MI/R period were measured to evaluate the extent of myocardial injury. The results indicated that the activity of SOD significantly decreased in the MI/R group compared with the sham group. Pretreatment with RS significantly increased SOD activity (Fig. 1A). LDH, CK-MB, MDA and troponin $\mathrm{I} / \mathrm{T}$ activities were significantly increased in
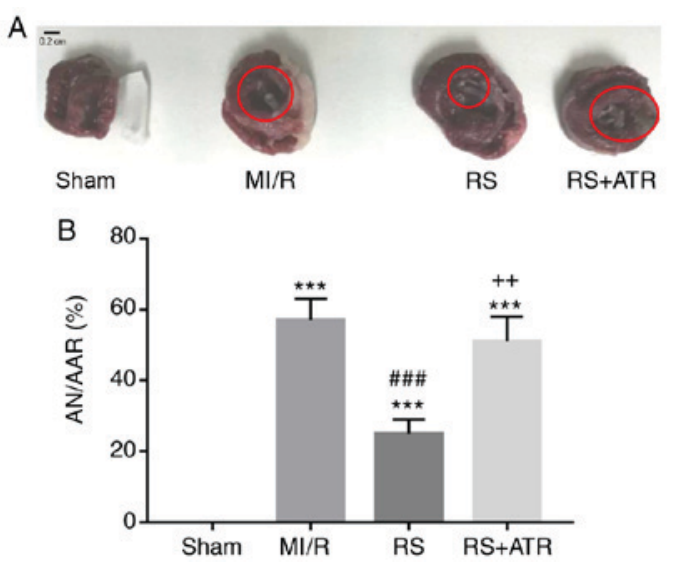

Figure 2. RS inhibits myocardial infarct size. A total of 48 rabbits were randomly divided into four groups, including the sham group, MI/R group, RS group and RS + ATR group. (A) Images of Evans blue/TTC-stained sections were captured. (B) The infarct size (\% AN/AAR) was detected in four groups. ${ }^{* * *} \mathrm{P}<0.001$ vs. the sham group; ${ }^{\# \#} \mathrm{P}<0.001$ vs. the MI/R group; ${ }^{++} \mathrm{P}<0.01$ vs. the $\mathrm{RS}$ group. $\mathrm{MI} / \mathrm{R}$, myocardial ischemia/reperfusion; $\mathrm{RS}$, rosuvastatin; ATR, atractyloside; AN, area of necrosis; AAR, area-at-risk. 
A

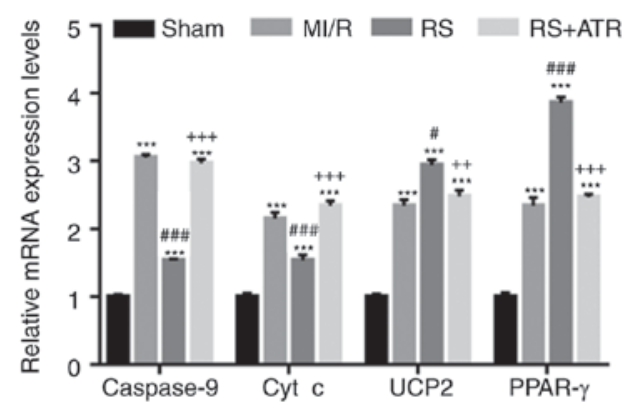

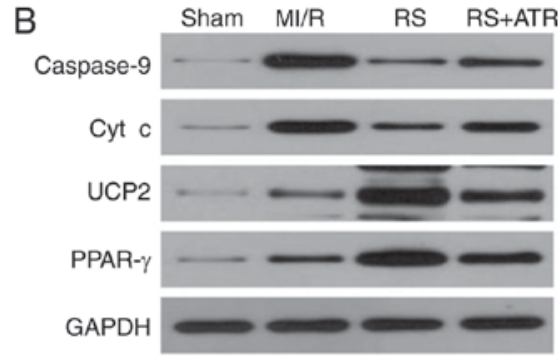

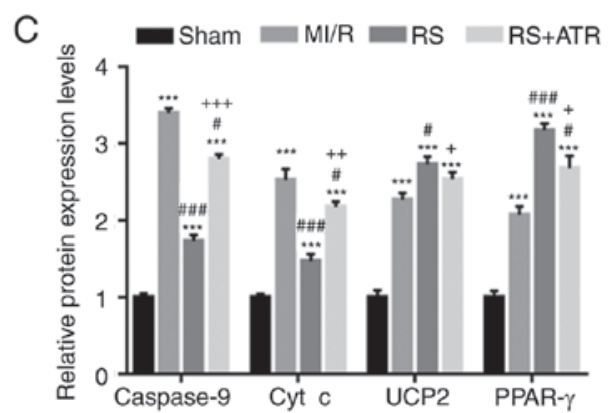

Figure 3. RS downregulates caspase- 9 and cyt c expression, and upregulates UCP2 and PPAR- $\gamma$ expression. A total of 48 rabbits were randomly divided into four groups, including the sham group, MI/R group, RS group and RS + ATR group. mRNA and protein expression levels of caspase-9, cyt c, UCP2 and PPAR- $\gamma$ were detected by (A) reverse transcription-quantitative polymerase chain reaction and (B) western blotting. (C) The results of western blotting were quantitatively analyzed. ${ }^{* * *} \mathrm{P}<0.001$ vs. the sham group; ${ }^{\#} \mathrm{P}<0.05$ and ${ }^{\# \# \#} \mathrm{P}<0.001$ vs. the MI/R group; ${ }^{+} \mathrm{P}<0.05,{ }^{++} \mathrm{P}<0.01$ and ${ }^{+++} \mathrm{P}<0.001$ vs. the $\mathrm{RS}$ group. $\mathrm{Cyt}$ c, cytochrome c; UCP2, mitochondrial uncoupling protein 2; PPAR- $\gamma$, peroxisome proliferator-activated receptor- $\gamma$; MI/R, myocardial ischemia/reperfusion; RS, rosuvastatin; ATR, atractyloside.

the MI/R group compared with the sham group, and RS significantly inhibited LDH, CK-MB, MDA and troponin I/T activities caused by MI/R. Furthermore, ATR significantly reversed whereas ATR markedly reversed the effect of RS (Fig. 1B-E).

$R S$ inhibits myocardial infarct size. To further confirm the direct effects of RS on myocardial MI/R injury, ischemic area and infarct size were measured in rabbits using the Evans blue/TTC method (Fig. 2A). The infarct size was analyzed and expressed as the percentage of AN/AAR. The results indicated that the infarct size was significantly increased in the MI/R group compared with the sham group. Treatment with RS significantly ameliorated the injury, whereas ATR markedly reversed the protective effect of RS (Fig. 2B).

$R S$ downregulates the expression of caspase-9 and cyt $c$, and upregulates the expression of UCP 2 and PPAR- $\gamma$. The effects of pretreatment with RS on expression of cell apoptosis-associated proteins caspase-9 and cyt c. UCP2 and PPAR- $\gamma$ expression levels were determined to elucidate the effects of RS on mitochondrial protection. The results revealed that compared with the sham group, caspase-9, cyt c, UCP2 and PPAR- $\gamma$ mRNA and protein expression levels significantly increased in the MI/R group (Fig. 3). Compared with the MI/R group, mRNA and protein expression of UCP2 and PPAR- $\gamma$ further increased, while caspase-9 and cyt-c expression decreased in response to RS treatment. Furthermore, ATR reversed the effects of RS (Fig. 3).

Pretreatment with $R S$ promotes cardiomyocyte viability, inhibits $L D H$ release and reduces $R O S$ production following
$O G D / R$ damage. The protective effect of preconditioning with RS was further studied on rat cardiomyocytes with OGD/R injury. Cardiomyocytes were divided into the following groups: Control, control $+\operatorname{siPPAR}-\gamma, \mathrm{OGD} / \mathrm{R}$, OGD $/ \mathrm{R}+$ siPPAR $-\gamma, \mathrm{RS}+\mathrm{OGD} / \mathrm{R}, \mathrm{RS}+\mathrm{OGD} / \mathrm{R}+\mathrm{siPPAR}-\gamma$, $\mathrm{ATR}+\mathrm{RS}+\mathrm{OGD} / \mathrm{R}, \mathrm{ATR}+\mathrm{RS}+\mathrm{OGD} / \mathrm{R}+\mathrm{siPPAR}-\gamma$. The cell viability was evaluated using the MTT and $\mathrm{LDH}$ release assays. OGD/R significantly inhibited myocardial viability compared with the control group and PPAR- $\gamma$ silencing in OGD/R cells further inhibited myocardial viability compared with the control and control $+\operatorname{siPPAR}-\gamma$ groups. Myocardial cell viability in the $\mathrm{RS}+\mathrm{OGD} / \mathrm{R}$ group was significantly increased compared with the OGD/R group. The results also indicated that treatment with ATR reversed the effect of RS. Furthermore, OGD/R and OGD/R + siPPAR- $\gamma$ significantly increased LDH activity compared with the control group. While LDH activity was significantly decreased in the RS + OGD/R group compared with the OGD/R group. Treatment with ATR significantly reversed the effect mediated by RS (Fig. 4 A, B). Furthermore, it was revealed that the mitochondrial and cellular ROS levels were significantly elevated in OGD/R and OGD $/ \mathrm{R}+\operatorname{siPPAR}-\gamma$ groups, compared with the control group. ROS content in $\mathrm{RS}+\mathrm{OGD} / \mathrm{R}$ group was significantly decreased compared with the OGD/R group. Treatment with ATR significantly reversed the effect mediated by RS (Fig. 5A, B).

Pretreatment with $R S$ decreases caspase-9 and cyt $c$ expression, and increases UCP 2 and PPAR- $\gamma$ expression following $O G D / R$ damage. To further elucidate the mechanism of RS preconditioning on myocardial OGD/R injury in rats, RT-qPCR and western blotting were performed. 

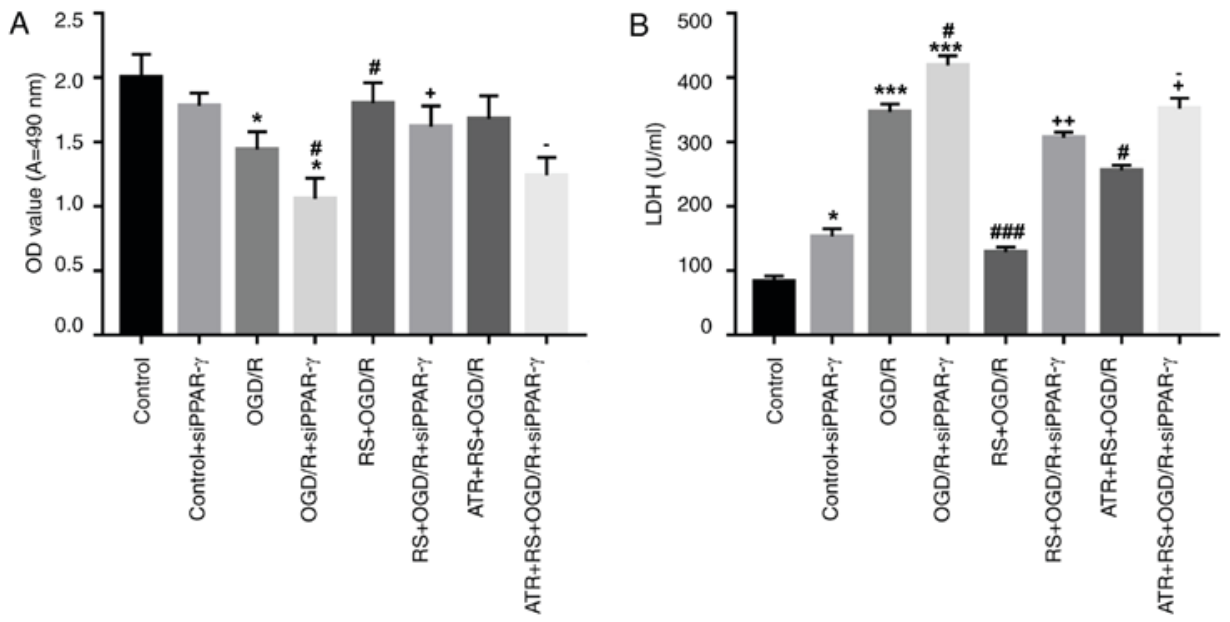

Figure 4. Pretreatment with RS promotes cardiomyocyte viability and inhibits LDH release following OGD/R damage. Cardiomyocytes were divided into the following groups: Control, control + siPPAR- $\gamma$, OGD/R, OGD/R + siPPAR- $\gamma, \mathrm{RS}+\mathrm{OGD} / \mathrm{R}, \mathrm{RS}+\mathrm{OGD} / \mathrm{R}+\mathrm{siPPAR}-\gamma, \mathrm{ATR}+\mathrm{RS}+\mathrm{OGD} / \mathrm{R}$, ATR + RS + OGD/R + siPPAR- $\gamma$. (A) Following reperfusion, cell viability was evaluated by MTT assay. (B) LDH activity was measured using LDH cytotoxicity assay. ${ }^{*} \mathrm{P}<0.05$ and ${ }^{* * *} \mathrm{P}<0.001$ vs. the control group; ${ }^{*} \mathrm{P}<0.05$ and ${ }^{\# \# \#} \mathrm{P}<0.001$ vs. the $\mathrm{OGD} / \mathrm{R}$ group; ${ }^{+} \mathrm{P}<0.05$ and ${ }^{++} \mathrm{P}<0.01$ vs. the $\mathrm{OGD} / \mathrm{R}+\mathrm{siPPAR}-\gamma$ group; OGD/R, oxygen-glucose deprivation/reperfusion; LDH, lactate dehydrogenase; OD, optical density; si, small interfering RNA; PPAR- $\gamma$, peroxisome proliferator-activated receptor- $\gamma ; \mathrm{RS}$, rosuvastatin; ATR, atractyloside.

A
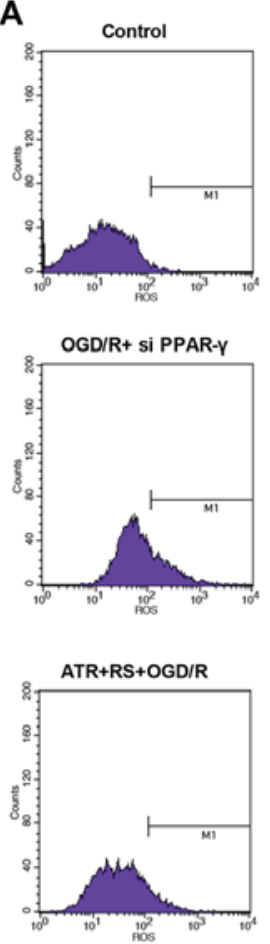

Control+ si PPAR-Y
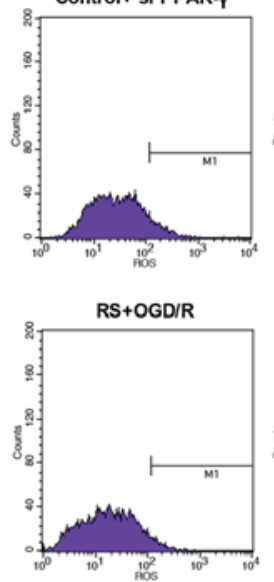

$A T R+R S+O G D / R+$ si PPAR-Y

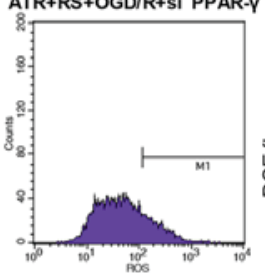

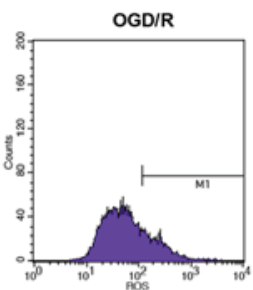

RS+OGD/R+ si PPAR-Y
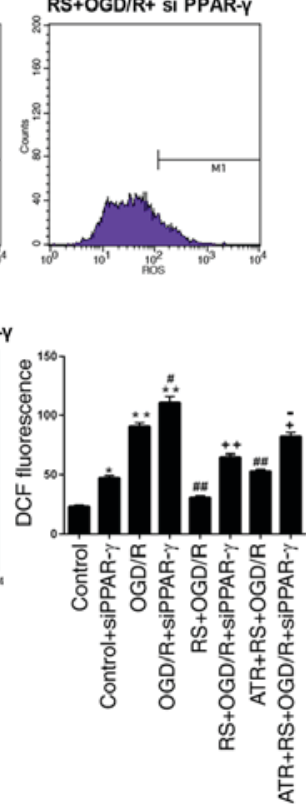

B
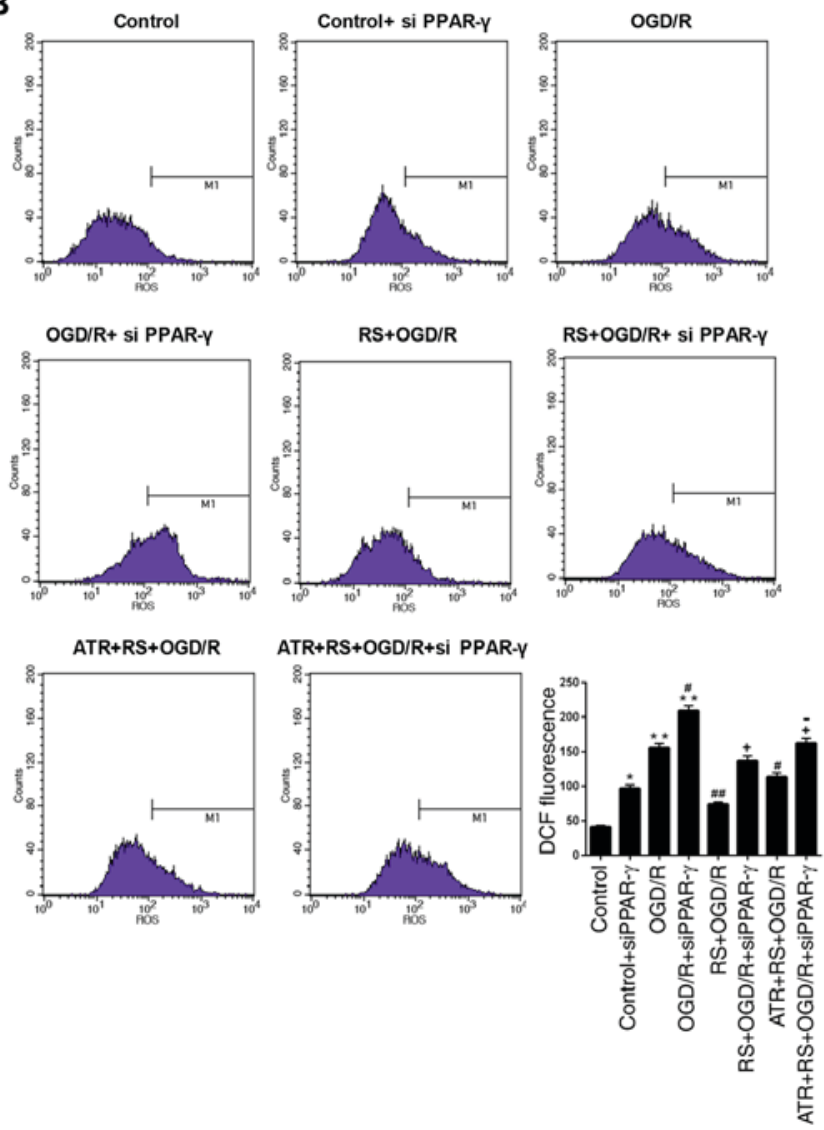

Figure 5. Pretreatment with RS reduces ROS production following OGD/R damage. Cardiomyocytes were divided into the following groups: Control, control + siPPAR- $\gamma$, OGD $/ \mathrm{R}$, OGD $/ \mathrm{R}+\operatorname{siPPAR}-\gamma, \mathrm{RS}+\mathrm{OGD} / \mathrm{R}, \mathrm{RS}+\mathrm{OGD} / \mathrm{R}+\mathrm{siPPAR}-\gamma, \mathrm{ATR}+\mathrm{RS}+\mathrm{OGD} / \mathrm{R}, \mathrm{ATR}+\mathrm{RS}+\mathrm{OGD} / \mathrm{R}+\mathrm{siPPAR}-\gamma . \mathrm{Flow}$ cytometry was used to determine the (A) mitochondrial and (B) cellular ROS levels. M1 indicates the cells that emitted a DCF signal and therefore the level of ROS production. ${ }^{*} \mathrm{P}<0.05$ and ${ }^{* *} \mathrm{P}<0.01$ vs. the control group; ${ }^{\#} \mathrm{P}<0.05$ and ${ }^{\# \#} \mathrm{P}<0.01$ vs. the OGD/R group; ${ }^{+} \mathrm{P}<0.05$ and ${ }^{++} \mathrm{P}<0.01$ vs. the $\mathrm{OGD} / \mathrm{R}+\mathrm{siPPAR}-\gamma$ group; 'P<0.05 vs. the RS + OGD/R + siPPAR- $\gamma$ group. OGD/R, oxygen-glucose deprivation/reperfusion; LDH, lactate dehydrogenase; DCF, 2',7'-dichlorofluorescein; ROS, reactive oxygen species; RS, rosuvastatin; ATR, atractyloside; si, small interfering RNA; PPAR- $\gamma$, peroxisome proliferator-activated receptor- $\gamma$.

As presented in Fig. 6, compared with the control group, caspase-9, cyt c, UCP2 and PPAR- $\gamma$ expression levels were significantly increased in the OGD/R group. The expression levels of caspase- 9 and cyt $c$ were lower in the RS + OGD/R and 

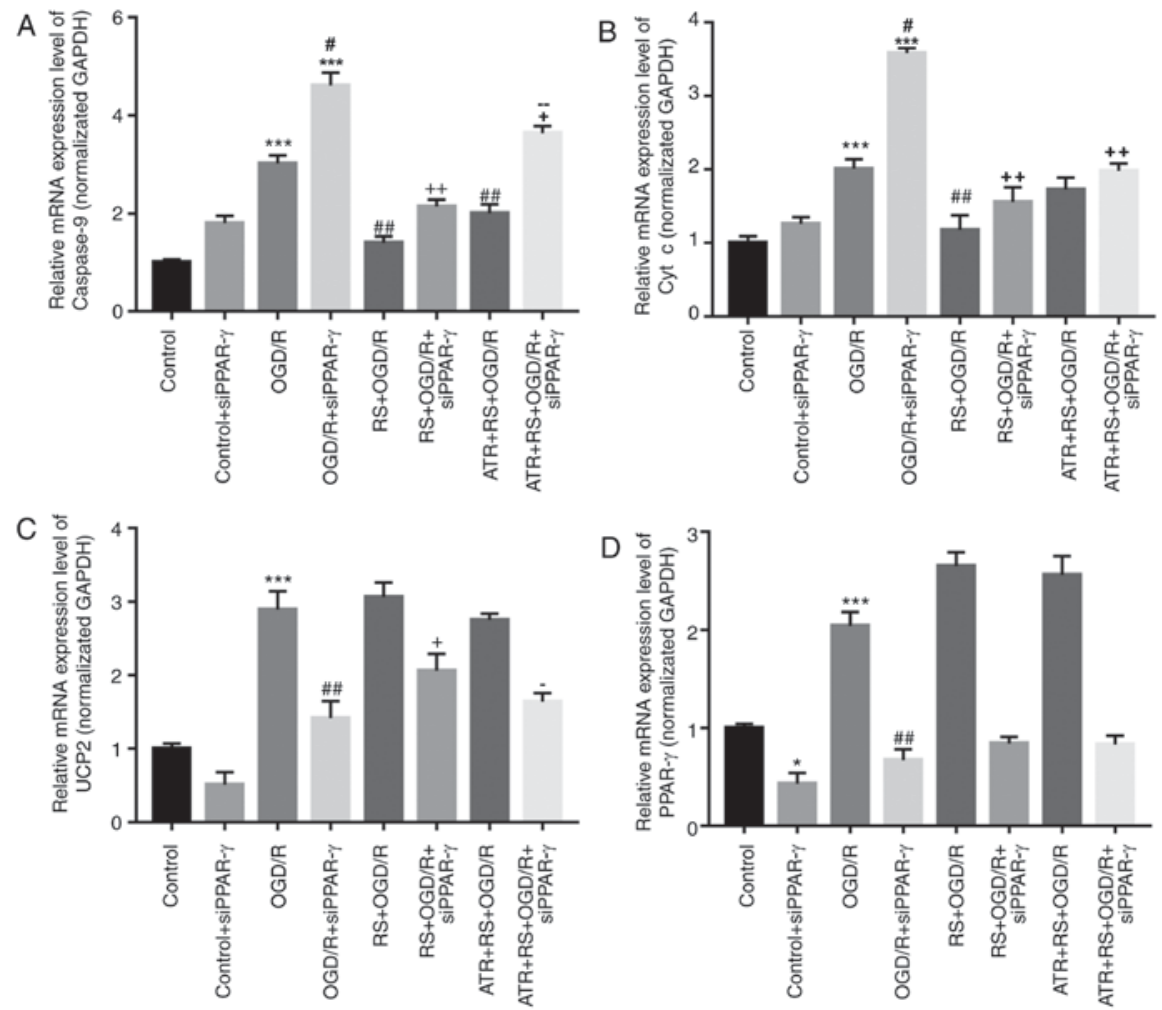

Figure 6. Pretreatment with RS decreases caspase- 9 and cyt c mRNA expression, and increases UCP2 and PPAR- $\gamma$ mRNA expression following OGD/R damage. Cardiomyocytes were divided into the following groups: Control, control + siPPAR- $\gamma$, OGD/R, OGD/R + siPPAR- $\gamma, \mathrm{RS}+\mathrm{OGD} / \mathrm{R}, \mathrm{RS}+\mathrm{OGD} / \mathrm{R}+\mathrm{siPPAR}-\gamma$, $\mathrm{ATR}+\mathrm{RS}+\mathrm{OGD} / \mathrm{R}, \mathrm{ATR}+\mathrm{RS}+\mathrm{OGD} / \mathrm{R}+$ siPPAR- $\gamma$. Reverse transcription-quantitative polymerase chain reaction was performed to analyze the mRNA expression levels of (A) caspase-9, (B) cyt c, (C) UCP2 and (D) PPAR- $\gamma$ in cardiomyocytes. ${ }^{*} \mathrm{P}<0.05$ and ${ }^{* * *} \mathrm{P}<0.001$ vs. the control group; ${ }^{*} \mathrm{P}<0.05$ and ${ }^{\# \#} \mathrm{P}<0.01$ vs. the $\mathrm{OGD} / \mathrm{R}$ group; ${ }^{+} \mathrm{P}<0.05$ and ${ }^{+} \mathrm{P}<0.01$ vs. the $\mathrm{OGD} / \mathrm{R}+\operatorname{siPPAR}-\gamma$ group; $\cdot \mathrm{P}<0.05$ and ${ }^{-\mathrm{P}}<0.01$ vs. the $\mathrm{RS}+\mathrm{OGD} / \mathrm{R}+$ siPPAR- $\gamma$ group. OGD/R, oxygen-glucose deprivation/ reperfusion; cyt c, cytochrome c; RS, rosuvastatin; ATR, atractyloside; si, small interfering RNA; PPAR- $\gamma$, peroxisome proliferator-activated receptor- $\gamma$; UCP2, mitochondrial uncoupling protein 2.

$\mathrm{RS}+\mathrm{OGD} / \mathrm{R}+$ si-PPAR- $\gamma$ groups compared with the OGD/R and $\mathrm{OGD} / \mathrm{R}+\mathrm{si}-\mathrm{PPAR}-\gamma$ groups, respectively. The expression of UCP2 2 and PPAR- $\gamma$ increased following RS preconditioning in the RS + OGD/R and RS + OGD/R + si-PPAR- $\gamma$ groups, compared with $\mathrm{OGD} / \mathrm{R}$ and $\mathrm{OGD} / \mathrm{R}+\mathrm{si}-\mathrm{PPAR}-\gamma$ groups, respectively. The effect of RS on the expression of caspase-9, cyt $\mathrm{c}$ and UCP2 was reversed by ATR (Fig. 6). The WB results in the expression of caspase-9, cyt $\mathrm{c}$ and PPAR- $\gamma$ had a similar trend to the mRNA data. However, although ATR reversed the effect of RS on UCP2 mRNA expression, this effect was not observed at the protein level (Fig. 7).

\section{Discussion}

Coronary heart disease (CHD) and atherosclerosis (AS) affect human health worldwide (35). Interventional cardiovascular therapy has greatly improved the clinical outcomes of patients with CHD (36). Restoring blood flow is indispensable for rescuing the ischemic myocardium, however, myocardial revascularization also causes damage, known as $\mathrm{MI} / \mathrm{R}$ injury (37). MI/R could aggravate the hemodynamic dysfunction and cause ischemia/reperfusion injury in the patient, which may eventually lead to mortality (38). Statins, commonly used drugs for treatment of AS and acute coronary syndrome (ACS), regulate the lipid metabolism and serve multiple pharmacological roles associated with the stability of atherosclerotic plaques, endothelial function and immune regulation (39). These pharmacological effects indicate that further investigation of statins in the context of cardiovascular disease may be beneficial for development of novel treatment methods. Therefore, the present study analyzed the direct effect and potential mechanism of RS in MI/R injury.

In the current study, an in vivo rabbit model of $\mathrm{MI} / \mathrm{R}$ was established using protocols described in previous studies $(40,41)$. Subsequently, the activities of SOD, LDH, CK-MB, MDA and troponin I/T in serum samples from each treatment group were evaluated. The results indicated that RS significantly enhanced the SOD activity, and reduced the LDH, CK-MB, MDA and troponin I/T activities compared with the MI/R group. ATR reversed the effects of RS. Furthermore, following Evans blue/TTC staining, it was revealed that RS markedly inhibited the myocardial infarct size compared to MI/R group. Expression levels of UCP2 and PPAR- $\gamma$ in serum samples from each treatment group were also determined. RS increased the UCP2 and PPAR- $\gamma$ expression levels compared to MI/R group; while the effect of RS was reversed by ATR. Based on these results, it can be hypothesized that treatment with RS prior to MI/R can reduce MI/R injury via upregulation of UCP2 and PPAR- $\gamma$ in vivo. ATR partially reversed the protective effects of RS.

The results obtained using RS in vivo were further tested using an in vitro model of MI/R to further elucidate the underlying mechanisms of action. In vitro, the $\mathrm{OGD} / \mathrm{R}$ injury was used to mimic the I/R damage in cardiomyocytes. The viability of cardiomyocytes from each treatment 


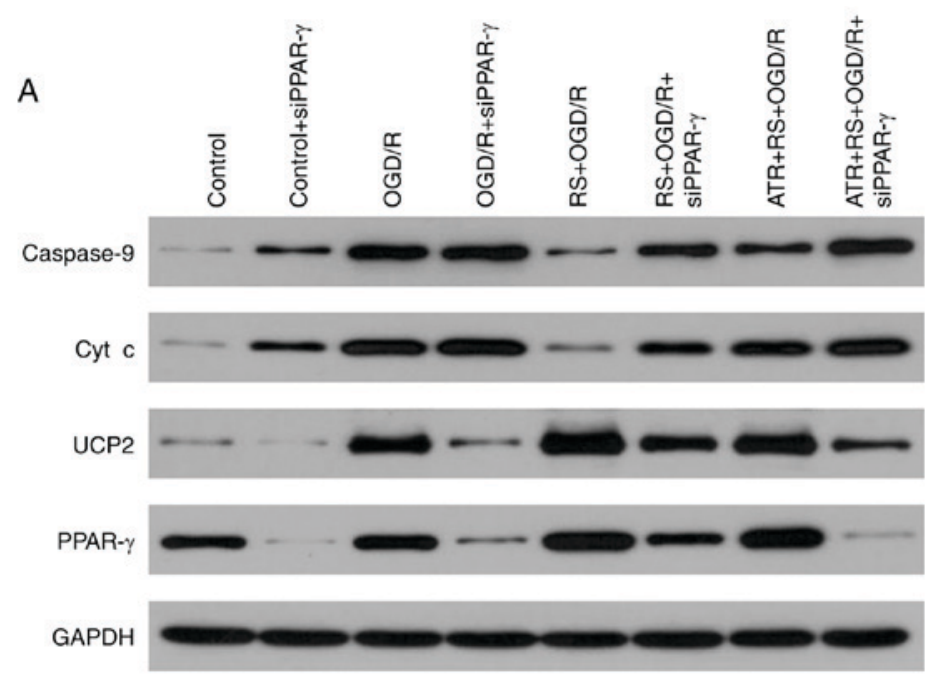

B

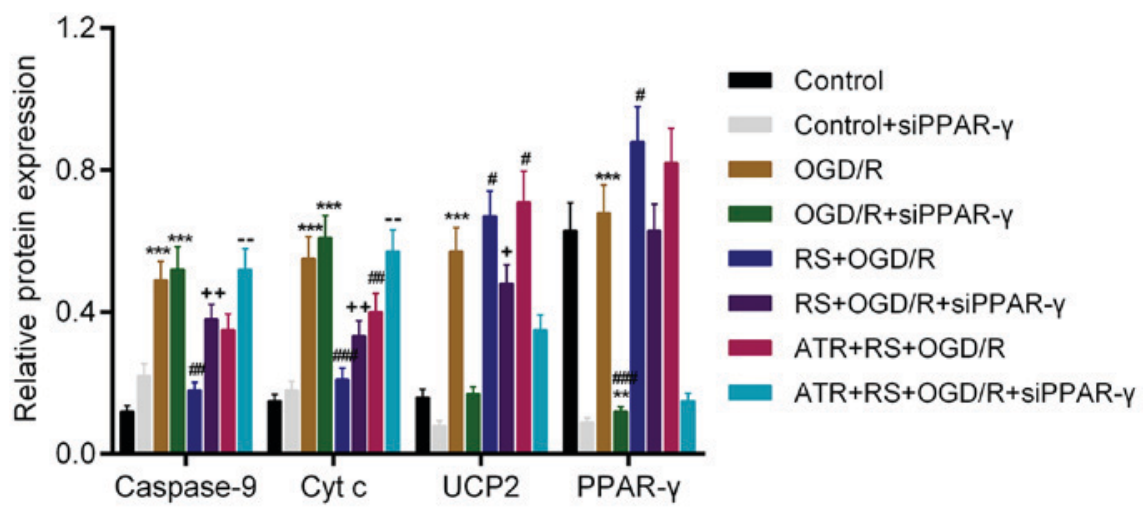

Figure 7. RS downregulates protein expression levels of caspase-9 and cyt c, and upregulates protein expression levels of UCP2 and PPAR- $\gamma$ following OGD/R damage. Cardiomyocytes were divided into the following groups: Control, control + siPPAR- $\gamma$, OGD/R, OGD/R + siPPAR- $\gamma, \mathrm{RS}+\mathrm{OGD} / \mathrm{R}$, $\mathrm{RS}+\mathrm{OGD} / \mathrm{R}+\mathrm{siPPAR}-\gamma, \mathrm{ATR}+\mathrm{RS}+\mathrm{OGD} / \mathrm{R}, \mathrm{ATR}+\mathrm{RS}+\mathrm{OGD} / \mathrm{R}+$ siPPAR- $\gamma$. (A) Western blot analysis was used to detect the protein expression levels of caspase-9, cyt c, UCP2 and PPAR- $\gamma$ in cardiomyocytes. (B) The protein expression levels were quantitatively analyzed according to the protein gray values. ${ }^{* *} \mathrm{P}<0.01$ and ${ }^{* * *} \mathrm{P}<0.001$ vs. the control group; ${ }^{\#} \mathrm{P}<0.05$ and ${ }^{\# \#} \mathrm{P}<0.01$ vs. the $\mathrm{OGD} / \mathrm{R}$ group; ${ }^{+} \mathrm{P}<0.05$ and ${ }^{++} \mathrm{P}<0.01$ vs. the OGD/R + siPPAR $-\gamma$ group; ${ }^{-} \mathrm{P}<0.01$ vs. the RS + OGD/R + siPPAR- $\gamma$ group. OGD/R, oxygen-glucose deprivation/ reperfusion; cyt c, cytochrome c; PPAR- $\gamma$, peroxisome proliferator-activated receptor- $\gamma$; UCP2, mitochondrial uncoupling protein 2; RS, rosuvastatin; ATR, atractyloside; si, small interfering RNA.

group was measured. The results revealed that silencing of PPAR- $\gamma$ inhibited the viability of cardiomyocytes (OGD/R group vs. OGD $/ \mathrm{R}+$ siPPAR- $\gamma$ group). $\mathrm{RS}$ enhanced the viability of myocardial cells suppressed by OGD/R. Mitochondria have been hypothesized to be the primary source of ROS following I/R injury (42). Excessive ROS production can cause damage of the antioxidative system, increase membrane permeability and cause calcium overdose during reperfusion (43). The increase in $\mathrm{Ca}^{2+}$ levels in the mitochondria may lead to the opening of the mitochondrial permeability transition pore, loss of MMP and increased ROS production (44). The interaction between ROS and $\mathrm{Ca}^{2+}$ may aggravate apoptotic cell injury during I/R (45). Therefore, the present study measured the mitochondrial and cellular ROS content in cardiomyocytes from each treatment group. According to the flow cytometry data, RS markedly suppressed ROS production enhanced by OGD/R both in mitochondria and intracellular space.

Caspase-9 and cyt c are known apoptosis-associated proteins $(46,47)$ and a recent study has indicated that the release of cyt c could induce the activation of caspase- 9 in gastric carcinoma cells (48). In the present study, the effects of RS on myocardial cells were further examined by detecting alterations in the mRNA and protein expression levels of caspase-9, cyt c, UCP2 and PPAR- $\gamma$. The results indicated that RS upregulated the expression levels of UCP2 and PPAR- $\gamma$ following OGD/R damage, while this pretreatment significantly reduced the expression of apoptosis-associated proteins, caspase- 9 and cyt $\mathrm{c}$ in myocardial cells. The expression levels of UCP2 and PPAR- $\gamma$, were up-regulated following OGD/R damage and further increased in the RS group. It may be hypothesized that $\mathrm{OGD} / \mathrm{R}$ promoted cell apoptosis and enhanced the expression of apoptosis-associated proteins, which may have activated the expression of UCP 2 and PPAR- $\gamma$ to protect the cells against apoptosis. It may be concluded that RS protected the myocardial cells against $\mathrm{OGD} / \mathrm{R}$ injury by up-regulating the expression of PPAR- $\gamma$ and UCP2.

In the present study, RS mitigated MI/R injury, increased SOD activity and decreased LDH, CK-MB, MDA and troponin I/T activities. RS also downregulated the expression of apoptosis-associated genes (caspase-9 and cyt c). RS suppressed 
the production of ROS, and ATR reversed the effect of RS. Therefore, it may be hypothesized that RS induces cardioprotective effects by suppressing ROS production and inhibiting mitochondria-mediated apoptosis.

In conclusion, in the present study RS inhibited myocardial infarct size and ROS in vivo and protected primary myocardial cells against OGD/R injury in vitro. Furthermore, RS decreased the expression levels of apoptosis-associated genes (caspase-9 and cyt c), and increased the expression of UCP2 and PPAR- $\gamma$. Furthermore, the effect of RS was reversed by ATR. The present study provided evidence for the use of RS as a potential agent for the treatment of cardiac injury.

\section{Acknowledgements}

Not applicable.

\section{Funding}

The present study was supported by the Quanzhou Science and Technology Planning Project (grant no. 2015Z80).

\section{Availability of data and materials}

All data generated and/or analyzed during this study are included in this published article.

\section{Authors' contributions}

LW wrote the main manuscript and analyzed the data. RL and LG performed the experiments. MH designed the study. All authors read and approved the final manuscript.

\section{Ethics approval and consent to participate}

The project protocol was approved by the Institutional Review Board of Fujian Province Medical Association.

\section{Consent for publication}

Not applicable.

\section{Competing interests}

The authors declare that they have no competing interests.

\section{References}

1. Cheng TO: Coronary arteriosclerotic disease existed in China over 2,200 years ago. Methodist Debakey Cardiovasc J 8: 47-48, 2012.

2. Libby P, Tabas I, Fredman G and Fisher EA: Inflammation and its resolution as determinants of acute coronary syndromes. Circ Res 114: 1867-1879, 2014.

3. Ma P, Han L, Lv Z, Chen W, Hu H, Tu J, Zhou X and Liu SM: In-hospital free fatty acids levels predict the severity of myocardial ischemia of acute coronary syndrome. BMC Cardiovasc Disord 16: 29, 2016.

4. Arnold JR, Karamitsos TD, van Gaal WJ, Testa L, Francis JM, Bhamra-Ariza P, Ali A, Selvanayagam JB, Westaby S, Sayeed R, et al: Residual ischemia after revascularization in multivessel coronary artery disease: Insights from measurement of absolute myocardial blood flow using magnetic resonance imaging compared with angiographic assessment. Circ Cardiovasc Interv 6: 237-245, 2013.
5. Torosoff MT, Sidhu MS and Boden WE: Impact of myocardial ischemia on myocardial revascularization in stable ischemic heart disease. Lessons from the COURAGE and FAME 2 trials. Herz 38: 382-386, 2013.

6. Frias Neto CA, Koike MK, Saad KR, Saad PF and Montero EF: Effects of ischemic preconditioning and cilostazol on muscle ischemia-reperfusion injury in rats. Acta Cir Bras 29 (Suppl 3): S17-S21, 2014.

7. Halladin NL: Oxidative and inflammatory biomarkers of ischemia and reperfusion injuries. Dan Med J 62: B5054, 2015.

8. Hermida $\mathrm{N}$ and Balligand JL: Low-density lipoprotein-cholesterol-induced endothelial dysfunction and oxidative stress: The role of statins. Antioxid Redox Signal 20: 1216-1237, 2014.

9. Kosmas CE, Alkhawam H, El-Hunjul M, Wagman G, Kahn MR Grady KM and Vittorio TJ: Statin-mediated low-density lipoprotein lowering in chronic congestive heart failure. Am J Med Sci 347: 14-22, 2014.

10. Barone E, Di Domenico F and Butterfield DA: Statins more than cholesterol lowering agents in Alzheimer disease: Their pleiotropic functions as potential therapeutic targets. Biochem Pharmacol 88: 605-616, 2014.

11. Gazzerro P, Proto MC, Gangemi G, Malfitano AM, Ciaglia E, Pisanti S, Santoro A, Laezza C and Bifulco M: Pharmacological actions of statins: A critical appraisal in the management of cancer. Pharmacol Rev 64: 102-146, 2012.

12. Kamada A, Yoshikawa Y, Domae E, Goda S, Okazaki J, Kawamoto A, Komasa Y and Ikeo T: Effect of statin on synthesis of bone morphogenetic protein-2 and extracellular matrix in human osteosarcoma cells. J Osaka Odontolo Soc 67: 2004

13. Adams SP, Sekhon SS and Wright JM: Lipid-lowering efficacy of rosuvastatin. Cochrane Database Syst Rev: CD010254, 2014.

14. Robertsen I, Asberg A, Granseth T, Vethe NT, Akhlaghi F, Ghareeb M, Molden E, Reier-Nilsen M, Holdaas H and Midtvedt K: More potent lipid-lowering effect by rosuvastatin compared with fluvastatin in everolimus-treated renal transplant recipients. Transplantation 97: 1266-1271, 2014.

15. Chen K, Li D, Zhang X, Hermonat PL and Mehta JL: Anoxia-reoxygenation stimulates collagen type-I and MMP-1 expression in cardiac fibroblasts: Modulation by the PPAR-gamma ligand pioglitazone. J Cardiovasc Pharmacol 44: 682-687, 2004.

16. Shao X, Wang M, Wei X, Deng S, Fu N, Peng Q, Jiang Y, Ye L, Xie $\mathrm{J}$ and Lin Y: Peroxisome proliferator-activated receptor- $\gamma$ : Master regulator of adipogenesis and obesity. Curr Stem Cell Res Ther 11: 282-289, 2016.

17. Ma T, Ma ZQ, Du XH, Yu QS, Wang R and Liu L: Effect of valsartan on ACAT-1 and PPAR- $\gamma$ expression in intima with carotid artery endothelial balloon injury in rabbit. Int J Clin Exp Med 8: 5527-5533, 2015.

18. Prathab Balaji S, Vijay Chand C, Justin A and Ramanathan M: Telmisartan mediates anti-inflammatory and not cognitive function through PPAR- $\gamma$ agonism via SARM and MyD88 signaling. Pharmacol Biochem Behav 137: 60-68, 2015.

19. Jin H, Gebska MA, Blokhin IO, Wilson KM, Ketsawatsomkron P Chauhan AK, Keen HL, Sigmund CD and Lentz SR: Endothelial PPAR- $\gamma$ protects against vascular thrombosis by downregulating P-selectin expression. Arterioscler Thromb Vasc Biol 35: 838-844, 2015.

20. Boss O, Muzzin P and Giacobino JP: The uncoupling proteins, a review. Eur J Endocrinol 139: 1-9, 1998.

21. De Marchi U, Castelbou C and Demaurex N: Uncoupling protein 3 (UCP3) modulates the activity of Sarco/endoplasmic reticulum Ca2+-ATPase (SERCA) by decreasing mitochondrial ATP production. J Biol Chem 286: 32533-32541, 2011.

22. Ozcan C, Palmeri M, Horvath TL, Russell KS and Russell RR III: Role of uncoupling protein 3 in ischemia-reperfusion injury, arrhythmias and preconditioning. Am J Physiol Heart Circ Physiol 304: H1192-H1200, 2013.

23. Wang X, Gong J, Liu X, Zhan R, Kong R, Zhao Y, Wan D, Leng X, Chen $M$ and Qian L: Expression of uncoupling protein 3 in mitochondria protects against stress-induced myocardial injury: A proteomic study. Cell Stress Chaperones 15: 771-779, 2010.

24. Hoerter J, Gonzalez-Barroso MD, Couplan E, Mateo P, Gelly C, Cassard-Doulcier AM, Diolez P and Bouillaud F: Mitochondrial uncoupling protein 1 expressed in the heart of transgenic mice protects against ischemic-reperfusion damage. Circulation 110: 528-533, 2004.

25. Chen GG, Yan JB, Wang XM, Zheng MZ, Jiang JP, Zhou XM, Cai B and Shen YL: Mechanism of uncoupling protein 2 mediated myocardial injury in hypothermic preserved rat hearts. Mol Med Rep 14: 1857-1864, 2016. 
26. Ji XB, Li XR, Hao-Ding, Sun Q, Zhou Y, Wen P, Dai CS and Yang JW: Inhibition of uncoupling protein 2 attenuates cardiac hypertrophy induced by transverse aortic constriction in mice. Cell Physiol Biochem 36: 1688-1698, 2015.

27. Villarroya F, Iglesias R and Giralt M: PPARs in the control of uncoupling proteins gene expression. PPAR Res 2007: 74364, 2007.

28. Oberkofler H, Klein K, Felder TK, Krempler F and Patsch W: Role of peroxisome proliferator-activated receptor-gamma coactivator-1alpha in the transcriptional regulation of the human uncoupling protein 2 gene in INS-1E cells. Endocrinology 147 966-976, 2006

29. Sachdeva J, Dai W, Gerczuk PZ and Kloner RA: Combined remote perconditioning and postconditioning failed to attenuate infarct size and contractile dysfunction in a rat model of coronary artery occlusion. J Cardiovasc Pharmacol Ther 19: 567-573, 2014

30. Wang F, Yin J, Lu Z, Zhang G, Li J, Xing T, Zhuang S and Wang N: Limb ischemic preconditioning protects against contrast-induced nephropathy via renalase. EBioMedicine 9: 356-365, 2016.

31. Wang F, Zhang G, Lu Z, Geurts AM, Usa K, Jacob HJ, Cowley AW, Wang N and Liang M: Antithrombin III/SerpinC1 insufficiency exacerbates renal ischemia/reperfusion injury. Kidney Int 88: 796-803, 2015.

32. Rutering J, Ilmer M, Recio A, Coleman M, Vykoukal J and Alt E: Improved method for isolation of neonatal rat cardiomyocytes with increased Yield of C-Kit+ cardiac progenitor cells. J Stem Cell Res Ther 5: 1-8, 2015.

33. Tao L, Bei Y, Li Y and Xiao J: Neonatal Rat Cardiomyocytes isolation, culture and determination of MicroRNAs' effects in proliferation. Methods Mol Biol 1733: 203-213, 2018.

34. Livak KJ and Schmittgen TD: Analysis of relative gene expression data using real-time quantitative PCR and the 2(-Delta Delta C(T)) method. Methods 25: 402-408, 2001.

35. Dalen JE, Alpert JS, Goldberg RJ and Weinstein RS: The epidemic of the 20 (th) century: Coronary heart disease. Am J Med 127: 807-812, 2014.

36. Faxon DP and Williams DO: Interventional cardiology: Current status and future directions in coronary disease and valvular heart disease. Circulation 133: 2697-2711, 2016.

37. Karu I, Tähepõld P, Ruusalepp A and Starkopf J: Pretreatment by hyperoxia-a tool to reduce ischaemia-reperfusion injury in the myocardium. Curr Clin Pharmacol 5: 125-132, 2010.

38. Ferdinandy P, Schulz R and Baxter GF: Interaction of cardiovascular risk factors with myocardial ischemia/reperfusion injury, preconditioning and postconditioning. Pharmacol Rev 59: 418-458, 2007.
39. Nissen SE, Tuzcu EM, Brewer HB, Sipahi I, Nicholls SJ, Ganz P, Schoenhagen P, Waters DD, Pepine CJ, Crowe TD, et al: Effect of ACAT inhibition on the progression of coronary atherosclerosis. N Engl J Med 354: 1253-1263, 2006.

40. Zhao XJ, Liu XL, He GX and Xu HP: Effects of single-dose atorvastatin on interleukin-6, interferon gamma and myocardial no-reflow in a rabbit model of acute myocardial infarction and reperfusion. Braz J Med Biol Res 47: 245-251, 2014.

41. Zhao ZG, Tang ZZ, Zhang WK and Li JG: Protective effects of embelin on myocardial ischemia-reperfusion injury following cardiac arrest in a rabbit model. Inflammation 38: 527-533, 2015.

42. Zhao ZQ: Oxidative stress-elicited myocardial apoptosis during reperfusion. Curr Opin Pharmacol 4: 159-165, 2004.

43. Zhao K, Zhao GM, Wu D, Soong Y, Birk AV, Schiller PW and Szeto HH: Cell-permeable peptide antioxidants targeted to inner mitochondrial membrane inhibit mitochondrial swelling, oxidative cell death and reperfusion injury. J Biol Chem 279: 34682-34690, 2004

44. Ding WX, Shen HM and Ong CN: Pivotal role of mitochondrial $\mathrm{Ca}(2+)$ in microcystin-induced mitochondrial permeability transition in rat hepatocytes. Biochem Biophys Res Commun 285: 1155-1161, 2001.

45. Simon HU, Haj-Yehia A and Levi-Schaffer F: Role of reactive oxygen species (ROS) in apoptosis induction. Apoptosis 5: 415-418, 2000.

46. Brentnall M, Rodriguez-Menocal L, De Guevara RL, Cepero E and Boise LH: Caspase-9, caspase-3 and caspase-7 have distinct roles during intrinsic apoptosis. BMC Cell Biol 14: 32 , 2013.

47. Skemiene K, Rakauskaite G, Trumbeckaite S, Liobikas J, Brown GCand Borutaite V: Anthocyanins block ischemia-induced apoptosis in the perfused heart and support mitochondrial respiration potentially by reducing cytosolic cytochrome c. Int J Biochem Cell Biol 45: 23-29, 2013.

48. Zhu X, Zhang K, Wang Q, Chen S, Gou Y, Cui Y and Li Q: Cisplatin-mediated c-myc overexpression and cytochrome c (cyt release result in the up-regulation of the death receptors DR4 and DR5 and the activation of caspase 3 and caspase 9, likely responsible for the TRAIL-sensitizing effect of cisplatin. Med Oncol 32: 133, 2015.

This work is licensed under a Creative Commons Attribution-NonCommercial-NoDerivatives 4.0 International (CC BY-NC-ND 4.0) License. 